\title{
PENINGKATAN KINERJA PEMASARAN MELALUI PELATIHAN PERENCANAAN PEMASARAN BAGI KELOMPOK USAHA KERAJINAN TAUFAN HANDRYCRAFT DI KOTA BATAM
}

\author{
Raymond \\ Universitas Putera Batam. Email: darayaja@gmail.com
}

\begin{abstract}
Many SMEs failed in the initial process of operations, one reason the failure of SMEs is the lack of analysis of marketing planning undertakings run. Marketing planning is a chart of a design to achieve a business goal. The aim is to create value for consumers in favorable conditions or in the current marketing concept of a mutually beneficial relationship. The method used is to give lectures and explanations about the theory of business marketing planning, and Participants will be given training in making marketing business planning in addition Participants will be given the opportunity to discuss the problems faced in making business marketing planning. The results obtained from this training are Participants are motivated to make Marketing planning and skilled in making marketing Planning
\end{abstract}

Keywords: Training, MSME, Marketing plan

\begin{abstract}
ABSTRAK
Banyak UMKM gagal dalam proses awal pengoperasionalannya, salah satunya alasan gagalnya UMKM tersebut adalah kurangnya analisa terhadap perencanaan pemasaran usaha yang dijalankan. Perencanaan pemasaran adalah suatu bagan dari suatu desain untuk mencapai suatu tujuan bisnis. Tujuannya adalah untuk menciptakan nilai bagi konsumen dalam kondisi tetap menguntungkan atau dalam konsep pemasaran saat ini suatu hubungan yang saling menguntungkan. Metode yang digunakan adalah memberikan ceramah dan pemaparan tentang teori perencanaan pemasaran usaha, dan Peserta diberi pelatihan dalam membuat perencanaan pemasaran usaha selain itu Peserta diberikan kesempatan untuk mendiskusikan permasalahan yang dihadapi dalam pembuatan perencanaan pemasaran usaha. Hasil yang diperoleh dari pelatihan ini adalah Peserta termotivasi membuat Perencanaan pemasaran dan terampil dalam membuat Perencanaan pemasaran
\end{abstract}

Kata Kunci: Pelatihan, UMKM, Perencanaan pemasaran.

\section{PENDAHULUAN}

Berdasarkan data dari Badan Pusat Statistik (BPS, 2014), sektor UMKM menyerap 97\% dari total tenaga kerja di Indonesia dan memberikan kontribusi terhadap PDB sebesar 59\% dan investasi sebesar 55\% dan hingga tahun 2012 di Indonesia terdapat usaha mikro sebanyak kurang lebih 55,85 juta unit usaha yang menyumbang 35,8\% PDB, usaha kecil sebanyak kurang lebih 629,418 unit usaha dan meyumbang 9,7\% PDB, usaha menengah sebanyak kurang lebih 48,997 unit usaha dan menyumbang 13,5\%. Dengan jumlah tersebut maka usaha di Indonesia terdiri dari 99,99\% UMKM dan hanya 0,01\% usaha yang berkategori usaha besar. 
Dari data tersebut, terbukti bahwa UMKM juga memilki peran penting dalam membangun pondasi ekonomi Indonesia. Pada beberapa kondisi perekonomian dunia yang beberapa tahun mengalami krisis ekonomi dunia, perekonomian Indonesia berada di kondisi stabil karena diuntungkan peran UMKM yang merupakan sektor usaha yang tangguh dan fleksibel dalam menghadapi dinamika ekonomi.

Menurut (Partomo, 2004) ada beberapa keunggulan yang dimiliki oleh UMKM jika dibandingkan dengan badan usaha lainnya diantaranya:

1. Inovasi dalam teknologi yang telah dengan mudah terjadi dalam pengembangan produk.

2. Hubungan kemanusiaan yang akrab didalam perusahaan kecil.

3. Kemampuan menciptakan kesempatan kerja cukup banyak atau penyerapannya terhadap tenaga kerja.

4. Fleksibilitas dan kemampuan menyesuaikan diri terhadap kondisi pasar yang berubah dengan cepat dibanding dengan perusahaan skala besar yang pada umumnya birokratis.

5. Terdapatnya dinamisme managerial dan peranan kewirausahaan.

Namun banyak UMKM gagal dalam proses awal pengoperasionalannya, salah satunya alasan gagalnya UMKM tersebut adalah kurangnya pemahaman UMKM terhadap perencanaan pemasaran. Perencanaan pemasaran adalah suatu bagan dari suatu desain untuk mencapai suatu tujuan. Menurut (Triastity, 2011) Marketing plan menyatakan latar belakang perusahaan, situasi persaingan, dan peluang, serta ancaman di pasar. Marketing plan secara integral sebagai bagian dari perencanaan bisnis, akan fokus pada sejarah pasar, kekuatan dan kelemahan pemasaran perusahaan, dan ancaman serta peiuang di pasar. Tujuannya adalah untuk menciptakan nilai bagi konsumen dalam kondisi tetap menguntungkan perusahaan, atau dalam konsep pemasaran saat ini, suatu hubungan yang saling menguntungkan.

Menurut (Dharmmesta, 2014) Keberhasilan sebuah UKM dalam mencapai tujuan bisnisnya tergantung pada kemampuan menjalankan fungsi pemasaran, Namun menurut (Trimurti, 2008) keberadaan UMKM pada saat ini hanya Terpaku pada keseragaman, kebiasaan dan tradisi, kualitas, corak serta motif, tenun yang diproduksi perajin tenun tradisional selama ini kurang mampu memenuhi permintaan maupun perubahan selera konsumen sehingga tidak mampu bersaing di pasaran. Salah satu alternatif untuk meningkatkan daya saing dan menciptakan nilai tambah produk adalah dengan melakukan perencanaan pemasaran.

Salah satu UMKM yang mengalami permasalahan berkaitan perencanaan pemasaran adalah Taufan Handy Craff dimana pada observasi yang dilakukan oleh Tim dosen Universitas Putera Batam, ditemukan bahwa kendala utama yang dihadapi Taufan Handy Craff adalah sulitnya dalam memasarkan produk mereka ketangan konsumen, hal ini dikarenakan kurangnya pemahaman Taufan Handy Craff terhadap perencanaan pemasaran mengakibatkan tidak berkembangnya usaha yang telah mereka jalani. Hal ini sesuai dengan temuan (Wibowo, 2015) yang menyatakan bahwa perencanaan pemasaran merupakan elemen penting bagi sebuah UMKM yang digunakan untuk mendapat gambaran mengenai strategi pemasaran untuk meningkatkan daya saing, dan 
untuk mengetahui seberapa efektif pelaksanaan strategi pemasaran yang telah dilakukan dan untuk meningkatkan pemahaman kelompok Taufan hendy craff terhadap perencanaan pemasaran maka salah cara yang ditempuh oleh Tim pengabdi adalah dengan melakukan pelatihan. Menurut (Mondy \& Noe, 2005) Pelatihan merupakan aktivitas yang dilakukan untuk meningkatkan pengetahuan, keterampilan dan sikap untuk meningkatkan kinerja saat ini dan masa yang akan datang

Untuk itu program ini akan mengarah pada pelatihan Marketing Plan pada Taufan Handycraft dan diharapkan dengan pelatihan ini dapat meningkatkan daya saing bagi objek yang dijadikan sasaran untuk program pengabdian masyarakat.

\section{METODE PELAKSANAAN}

Untuk memperoleh manfaat dari pengabdian ini serta dapat diimplementasikan, maka metode yang ditawarkan dalam pengabdian ini adalah sebagai berikut:

1. Langkah 1 (Metode ceramah)

Tim Dosen memberikan ceramah dan pemaparan tentang teori Perencanaan pemasaran

2. Langkah 2 (Metode Tutorial)

Peserta akan diberi Pembinaan dalam membuat Perencanaan pemasaran mulai dari biaya investasi sampai dengan analisis sosial ekonomi

3. Langkah 3 (Metode diskusi)

Peserta akan diberikan kesempatan untuk mendiskusikan permasalahan yang dihadapi dalam pembuatan Perencanaan pemasaran.

Selanjutnya adalah tahap evaluasi agar diketahui seberapa jauh keberhasilan dari kegiatan pelatihan ini, berikut disajikan tabel 1.1 evaluasi dalam pelatihanPerencanaan pemasaran ini :

Tabel 1.1. Evaluasi dalam Pembinaan Perencanaan pemasaran

\begin{tabular}{|l|l|l|}
\hline \multicolumn{1}{|c|}{ Tujuan } & Indikator ketercapaian & Tolak ukur \\
\hline $\begin{array}{l}\text { Peserta termotivasi } \\
\text { membuat Perencanaan } \\
\text { pemasaran }\end{array}$ & $\begin{array}{l}\text { Peserta mau Membuat } \\
\text { Perencanaan pemasaran }\end{array}$ & $\begin{array}{l}\text { Peserta yang mau } \\
\text { Perencanaan pemasaran } \\
\text { mengangkat tangan }\end{array}$ \\
\hline $\begin{array}{l}\text { Peserta mampu terampil } \\
\text { dalam membuat } \\
\text { Perencanaan pemasaran }\end{array}$ & $\begin{array}{l}\text { Peserta mampu } \\
\text { membuat beberapa } \\
\text { aspek dalam } \\
\text { Perencanaan pemasaran }\end{array}$ & $\begin{array}{l}\text { Peserta memiliki analisa } \\
\text { Perencanaan pemasaran }\end{array}$ \\
\hline
\end{tabular}

Sumber : Penulis 2017

\section{HASIL DAN PEMBAHASAN}

Pelaksanaan kegiatan dilaksanakan secara bertahap selama Tiga kali pertemuan yang dijabarkan sebagai berikut : 


\section{Hasil}

Hasil kegiatan diuraikan berdasarkan pada setiap rincian materi dan kegiatan yang dilakukan. Pertama, pada materi awal yang membahas mengenai Pemahaman materi tentang cara menyusun perencanaan pemasaran disambut dengan antusias oleh para peserta yang diketuai oleh Ibu salmah hani, peserta yang berjumlah 20 orang dari kelompok kerajinan pada umumnya belum mengetahui komponen penting dalam perencanaan pemasaran, seperti situasi pasar, situasi produk, situasi pesaing, situasi lingkungan makro, dan analisis kekuatan, kelemahan peluang dan ancaman, selama pelatihan Peserta diberikan kesempatan untuk mendiskusikan permasalahan yang dihadapi dalam pembuatan perencanaan pemasaran dan banyak pertanyaan yang diajukan oleh peserta dalam penyampaian materi kali ini, seperti persoalan pemasaran produk, sulitnya mempromosikan produk, kesulitan dalam menghadapi pesaing, penentuan harga dan berbagai persoalan lainnya yang selama ini dihadapi oleh kelompok kerajinan tangan tersebut.

Penyampain materi kedua lebih ditekankan pada pemahaman materi tentang Peran riset pemasaran yang lebih ditekankan pada memahami konsumen dan permintaan konsumen hal sangat penting agar produk yang ditawarkan oleh para pengrajin sesuai dengan keinginan dan kebutuhan konsumen, tidak berbeda dengan kegiatan pertama para peserta masih asing dengan istilah riset pemasaran, untuk itu dalam pelatihan ini kami bekali peserta bagaimana menempatkan diri pada konsumen, berbicara dengan konsumen, mengetahui keinginan konsumen dengan melakuakan kajian sederhana. Dalam penyampaian materi ini peserta sangat focus pada bagaimana cara memahami konsumen karena salah satu permasalahan utama mereka dalam memasarkan produk adalah banyak produk yang mereka tawarkan tidak sesuai dengan keinginan konsumen.

Pada penyampain materi ketiga pengabdi Memberikan pemahaman materi tentang cara membuat Laporan perencanaan pemasaran, pada penyampaian materi ketiga ini peserta diajarkan bagaimana membuat laporan perencanaan pemasaran hal ini sangat penting karena dengan materi ini para peserta dapat menawarkan produk dan jasa mereka kepada konsumen secara efektif dan efisien, materi ini difokuskan pada bagaimana mencantumkan target pasar, cara memasarkan produk, strategi membangun relasi, prospek pelanggan, cara melakukan transaksi, penjualan dan perencanaan keuangan. Penyampaian materi ini berjalan dengan baik. Secara berkelompok, peserta bekerja sama membuat laporan perencanaan pemasaran untuk kemudian dibahas secara kelompok. Beberapa kelompok sangat antusias dalam mengerjakan laporan perencanaan pemasaran ini.

\section{Evaluasi pelaksanaan kegiatan}

Pada pelaksanaan kegiatan pengabdian kepada masyarakat ini para peserta dari Taufan Handy Craff sangat antusias saat mengikuti pelatihan perencanaan pemasaran hal ini dikarenakan, peserta kegiatan ini yang berjumlah 20 orang memiliki keinginan sangat serius untuk mengembangkan usaha mereka untuk menjadi lebih kompetitif. Antusiasme peserta dalam mengikuti pelatihan ini menunjukkan bahwa para pelaku 
UMKM tersebut menyadari bahwa untuk sukses dalam menjalankan usaha diperlukan perencanaan pemasaran yang baik. Karena dengan hal tersebut segala permasalahan yang selam ini dihadapi oleh peserta dari taufan handy craff bisa teratasi.

Hasil yang diperoleh dari kegiatan pertama yaitu berkaitan dengan Pemahaman materi tentang cara menyusun perencanaan pemasaran dari pemaparan materi dan pelatihan yang diberikan para peserta pada akhirnya bisa menganalisis berbagai hal berkaitan tentang perencanaan pemasaran yaitu, situasi pasar, situasi produk, situasi pesaing, situasi lingkungan makro, dan analisis kekuatan, kelemahan peluang dan ancaman.

Selanjutnya, hasil dari pertemuan kedua yang membahas mengenai Peran riset pemasaran dan bagaimana cara memahami konsumen dan permintaan konsumen. Seperti yang sudah dijelaskan pada bagian sebelumnya bahwa penyampaian materi ini juga berjalan dengan baik, dimana peserta sangat fokus pada bagaimana cara memahami konsumen, implikasi dari hasil pengabdian pada pertemuan kedua ini peserta mampu.

Hasil berikutnya berkaitan tentang pembuatan Laporan perencanaan pemasaran peserta menunjukan antusiasme yang tinggi dan hasil dari kegiatan ini Peserta memiliki analisa perencanaan pemasaran selain itu para peserta mampu membuat target pasar, cara memasarkan produk, strategi membangun relasi, prospek pelanggan, cara melakukan transaksi penjualan dan membuat perencanaan keuangan.

\section{Evaluasi pelaksanaan kegiatan}

Hasil evaluasi pelatihan perencanaan pemasaran yang dilakukan bagi taufan handy craff dilakukan agar diketahui seberapa jauh keberhasilan dari kegiatan yang telah dilakukan, berikut hasil evaluasi dalam Pelatihan perencanaan pemasaran yang telah dilaksanakan pertama Tujuan dari diselenggarankannya pelatihan perencanaan pemasaran bagi Kelompok Usaha Kerajinan Taufan Handrycraft adalah agar para peserta termotivasi dalam membuat perencanaan pemasaran, selain itu tujuan dari lain dari diselenggarakannya pelatihan ini adalah peserta mampu membuat laporan perencanaan pemasaran dan indikator dari ketercapaian tujuan tersebut adalah pertama peserta mau membuat perencanaan pemasaran dan kedua peserta mampu membuat beberapa aspek dalam perencanaan pemasaran, tolak ukur keberhasilan dari pelaksanaan pelatihan perencanaan pemasaran ini adalah peserta yang ikut dalam pelatihan perencanaan pemasaran ini yaitu kelompok usaha kerajinan taufan handry caraff memiliki kemampuan dalam melakukan analisa dalam perencanaan pemasaran.

\section{Keberlanjutan dari hasil kegiatan}

Keberlanjutan dari hasil kegiatan Pembinaan perencanaan pemasaran ini antara lain, Pertama, Seluruh peserta mampu membuat perencanaan pemasaran. Kedua, Peserta mampu menetukan aspek pemasaran dari sebuah usaha. Ketiga, Peserta yang berpartisipasi dalam program pembinaan ini, diharapkan kedepannya tidak hanya berasal dari satu kelompok usaha dikota Batam saja namun dari beberapa Kelompok usahan masyarakat yang berbeda. 


\section{SIMPULAN}

Berdasarkan pengabdian yang telah dilakukan maka dapat diambil beberapa kesimpulan yang dianggap perlu, hal ini dimaksudkan supaya dapat menjadi pembelajaran bagi pengabdi, obyek pengabdian dan seterusnya adalah pembaca. Berikut adalah beberapa kesimpulan yang dapat diambil berdasarkan kegiatan pengabdian yang telah dilakukan, tema pengabdian kepada masyarakat ini adalah Pelatihan perencanaan pemasaran bagi kelompok usaha kerajinan Taufan Handrycraft di Kota Batam, setelah pelaksanaan pelatihan perencanaan pemasaran ini Peserta memiliki pemahaman tentang pembuatan perencanaan pemasaran. Selain itu, Peserta juga telah dapat memahami mengenai ruang lingkup dari perencanaan pemasaran. terahir, setelah pelaksanaan pelatihan ini berahir seluruh Peserta telah mampu dan dapat membuat perencanaan pemasaran

\section{DAFTAR RUJUKAN}

BPS. (2014). Batam Dalam Angka. Batam.

Dharmmesta, B. S. (2014). Peran Pemasaran dalam Perusahaan dan Masyarakat.

Mondy, \& Noe. (2005). Human Resource Management (9th ed.). Pearson Prentice Hall.

Partomo. (2004). Usaha kecil dan menengah dan koperasi. Working Paper Series No.9.center for Industry and SMEs Studies.

Triastity, R. (2011). Marketing Plan Sebagai Upaya Pencapaian Strategi Pemasaran Perusahaan Jangka Panjang. Jurnal Ekonomi Dan Kewirausahaan, 11(1), 38-47.

Trimurti. (2008). Model Pelatihan Kewirausahaan Berbasis Penerapan Teknologi Tenun Ikat. Jurnal Ekonomi Dan Kewirausahaan, 8(1), 96-103.

Wibowo, D. H. (2015). Analisis Strategi Pemasaran Untuk Meningkatkan Daya Saing Umkm ( Studi pada Batik Diajeng Solo ). Jurnal Administrasi Bisnis, 29(1), 59-66. 